\title{
UPAYA PENINGKATAN KEMAMPUAN MENULIS KARANGAN DALAM MATA PELAJARAN BAHASA INDONESIA MELALUI MEDIA GAMBAR SERI
}

\author{
Tati Rohayati \\ SD Negeri I Karangsambung, Jl. KH Khoer Affandi No. 164, Tasikmalaya, Indonesia \\ Email: mamannnn1403i@gmail.com
}

\begin{abstract}
This research was motivated by the low ability of writing composition in fourth grade students of SD Negeri I Karangsambung, Tasikmalaya City. In addition, the low ability of students in writing composition is caused by the lack of media used in the teaching and learning process, and the use of conventional methods. The purpose of this study is to determine whether or not the series pictures media can improve the students' ability to write composition in the Indonesian language subject to the fourth grade students of SD Negeri I Karangsambung, Tasikmalaya City. This research is a classroom action research conducted in the fourth grade of SD Negeri I Karangsambung, Tasikmalaya City, involving the total number of 39 students. Based on the results of research and discussion, it can be concluded that the use of series pictures media can improve students' ability to write composition in Indonesian subject of fourth grade students in SD Negeri I Karangsambung Kota Tasikmalaya in the 2017/2018 school year. In the first cycle, the students' completeness of learning to write reached $46.15 \%$ with an average value of 66.03 ; and in the second cycle, the completeness of the students increased to $71.79 \%$ with an average value of 72.21 . Then, in the third cycle, students' learning completeness became more increased (94.87\%) with an average score of 80.44 .
\end{abstract}

Keywords: Writing Composition, Indonesian Language, Series Pictures Media

\begin{abstract}
ABSTRAK
Penelitian ini dilatarbelakangi oleh rendahnya kemampuan menulis karangan pada siswa kelas IV SD Negeri I Karangsambung Kota Tasikmalaya. Selain itu, rendahnya kemampuan siswa dalam menulis karangan disebabkan oleh kurangnya media yang digunakan dalam proses belajar mengajar dan metode yang digunakan masih konvensioanal. Tujuan dari penelitian ini adalah untuk mengetahui media gambar seri dapat meningkatkan kemampuan siswa dalam menulis karangan pada mata pelajaran Bahasa Indonesia siswa kelas IV SD Negeri I Karangsambung Kota Tasikmalaya. Penelitian ini merupakan penelitian tindakan kelas yang dilakukan pada kelas IV SD Negeri I Karangsambung Kota Tasikmalaya yang berjumlah 39 siswa. Berdasarkan hasil penelitian dan pembahasan maka dapat disimpulkan bahwa penggunaan media gambar seri dapat meningkatkan kemampuan siswa dalam menulis karangan pada mata pelajaran bahasa Indonesia pada siswa kelas IV SD Negeri I Karangsambung Kota Tasikmalaya tahun ajaran 2017/2018. Pada siklus I ketuntasan belajar menulis siswa baru mencapai $46,15 \%$ dengan nilai rata-rata sebesar 66,03; dan pada siklus II ketuntasan siswa meningkat menjadi $71,79 \%$ dengan nilai rata-rata 72,21 . Selanjutnya pada siklus III ketuntasan belajar siswa menjadi lebih meningkat mencapai 94,87\% dengan nilai rata-rata sebesar 80,44.
\end{abstract}

Kata Kunci: Menulis Karangan, Bahasa Indonesia, Media Gambar Seri

Cara sitasi: Rohayati, T. (2021). Upaya Peningkatan Kemampuan Menulis Karangan dalam Mata Pelajaran Bahasa Indonesia Melalui Media Gambar Seri. J-KIP (Jurnal Keguruan dan IImu Pendidikan), 2 (1), 85-90. 


\section{PENDAHULUAN}

Pengajaran bahasa Indonesia pada hakikatnya adalah pengajaran keterampilan berbahasa. Keterampilan-keterampilan berbahasa yang perlu ditekankan pada pengajaran bahasa Indonesia adalah keterampilan mendengarkan, berbicara, membaca dan menulis (Slamet, 2007). Menulis adalah keterampilan yang produktif karena menulis merupakan komunikasi secara tidak langsung yang menghasilkan tulisan (Tarigan, 1987). Keterampilan menulis membutuhkan perhatian yang lebih karena selama ini posisi menulis dalam pengajaran keterampilan berbahasa selalu diletakkan dalam urutan terakhir. Meskipun menulis diposisi terakhir bukan berarti menulis itu tidak penting.

Keterampilan menulis sangat penting untuk dikuasai para siswa. Keterampilan menulis akan memberikan banyak manfaat dalam kehidupan pada masa sekarang ini. Menulis merupakan suatu kegiatan yang penting untuk menuangkan pikiran, gagasan atau pendapat, ide maupun perasaan seseorang. Menulis sebagai suatu keterampilan berbahasa yang dipergunakan untuk berkomunikasi secara tidak langsung (Putra, 2016). Pada pembelajaran menulis di SD kelas tinggi, standar kompetensi yang tercantum dalam KTSP adalah mengungkapkan pendapat dan perasaan ke dalam bentuk tulisan baik karangan, pantun maupun puisi. Dewasa ini kegiatan menulis masih dipandang sebagai kegiatan berbahasa yang paling sulit dibandingkan dengan kegiatan berbahasa lainnya. Oleh karena itu, perlu dicari pendekatan, metode, dan teknik yang dapat mempermudah kegiatan menulis (Slamet, 2007).

Pada kenyataannya kegiatan menulis belum berjalan dengan baik dan belum menarik perhatian siswa sehingga hasil yang didapat pun kurang memuaskan. Rendahnya keterampilan menulis karangan disebakan oleh kurangnya keterampilan siswa dalam menuangkan ide dengan baik, pengembangan kerangka karangan, dan penyusunan kalimat serta kosakata yang digunakan masih terbatas. Selain itu juga disebabkan oleh kurangnya media yang digunakan dalam belajar, masih diguankannya metode belajar yang konIVensional dan siswa membutuhkan waktu yang lama ddalam menulis. Akibatnya hanya sekitar $20 \%$ siswa yang dapat mencapai kriteria ketuntasan minimal. Kriteria ketuntasan minimal yang ditetapkan oleh sekolah ini adalah 64 .

Peran guru di sini sangat penting dalam mengarahkan keterampilan menulis. Guru harus dapat mengajarkan keterampilan menulis secara efisien, efektif, dan menarik. Guru dapat menggunakan metode dan media yang inovatif dan kreatif sehingga akan menarik perhatian siswa untuk menulis (Tarigan, 1987).

Pada kenyataannya masih banyak guru yang belum bisa mengoptimalkan penggunaan media dalam kegiatan belajar mengajar. Seorang guru harus mampu memilih media yang tepat dan sesuai supaya siswa dapat tertarik untuk menulis. Media Gambar Seri adalah salah satu media pembelajaran yang baik yang dapat mengasah keterampilan menulis siswa dan membuat pembelajaran menjadi menyenangkan karena memang dalam kegiatan belajar sangat diperlukan interaksi positif yang terjadi antara guru dan siswa yang menyenangkan dan tidak membosankan. Oleh karena itu rumusan masalah pada penelitian ini adalah: Apakah penggunaan media gambar seri dapat meningkatkan kemampuan siswa dalam menulis karangan pada mata pelajaran Bahasa Indonesia siswa kelas IV SD Negeri I Karangsambung Kota Tasikmalaya?.

\section{METODE PENELITIAN}

\section{A. Subjek dan Waktu Penelitian}

1. Subjek Penelitian

Subjek penelitian ini adalah siswa kelas IV SD Negeri I Karangsambung Kota Tasikmalaya yang berjumlah 39 siswa.

2. Waktu Penelitian

Penelitian dilaksanakan pada siswa kelas IV SD Negeri I Karangsambung Kota Tasikmalaya Tahun Pelajaran 2017/2018, penelitian tindakan kelas ini dilaksanakan sebanyak tiga siklus dimana dalam setiap siklus dilaksanakan sebanyak dua kali 
pertemiuan. Siklus I dilaksanakan pada tanggal 5 dan 8 September dan siklus II dilaksanakan pada tanggal 19 dan 22 September 2017 selanjutnya siklus III dilaksanakan pada tanggal 10 dan 13 Oktober 2017.

\section{B. Prosedur Penelitian}

\section{Pra Siklus}

Dalam pra siklus ini peneliti melakukan tanya jawab dengan guru kelas IV. Peneliti dan guru kolaborator mendiskusikan rancangan tindakan yang akan dilakukan dalam penelitian. Peneliti juga mengumpulkan data diri siswa kelas IV dan data nilai siswa kelas IV dalam pembelajaran menulis karangan tanpa menggunakan media gambar seri.

Dalam data tersebut masih banyak siswa yang belum mencapai ketuntasan minimal. Kriteria Ketuntasan Minimal yang ditetapkan oleh sekolah untuk mata pelajaran bahasa Indonesia adalah 75. Data-data tersebut dijadikan sebagai acuan dalam perencanaan penelitian selanjutnya.

\section{Siklus I}

a. Perencanaan

Pada tahap perencanaan ini peneliti berdiskusi dengan guru kolabarator untuk merencanakan tindakan penelitian. Peneliti juga mempersiapkan materi yang diajarkan kepada siswa.

b. Pelaksanaan

Dalam penelitian ini peneliti bertindak sebagai guru dan pengamatan dilakukan oleh rekan guru. Pada kegiatan inti, guru menjelaskan materi tentang menulis karangan dengan menggunakan media pembelajaran gambar seri.

c. Observasi

Pelaksanaan observasi dilakukan selama kegiatan belajar mengajar berlangsung. Observasi ini dibantu oleh rekan guru kelas IV SD Negeri I Karangsambung Kota Tasikmalaya. Pengamatan ini dimaksudkan untuk mengetahui sejauh mana keberhasilan guru dalam mengajarkan materi dengan menggunakan media gambar seri. Aspek yang di amati dalam pengamatan ini adalah aspek yang mencakup keterampilan guru dalam mengajar.

d. Refleksi

Hasil yang didapat dari pelaksanaan tindakan penelitian dan observasi peneliti kemudian melakukan analisis dan refleksi. Refleksi ini bertujuan untuk menemukan kekurangan dalam perencanaan dan pelaksanaan tindakan untuk diperbaiki pada siklus selanjutnya.

\section{Siklus II}

a. Perencanaan

Tahap perencanaan pada siklus II ini mengacu pada hasil refleksi pada siklus I. Kekurangan yang terjadi pada siklus I diperbaiki dalam siklus II ini.

b. Pelaksanaan

Dalam tahap ini peneliti bertindak sebagai guru. Pengamatan dilakukan oleh rekan guru. Kegiatan pembelajaran membahas mengenai materi tentang penyusunan kalimat dan penulisan paragraf dengan ejaan yang benar dengan media pembelajaran gambar seri.

c. Observasi

Pengamatan dilakukan secara langsung terhadap proses kegiatan belajar mengajar yang terjadi di dalam kelas. Lembar pengamatan yang digunakan untuk mengamati keterampilan guru sama dengan lembar yang digunakan pada siklus I. Kegiatan observasi ini dimaksudkan untuk mengetahui apakah kekurangan teknik pengajaran pada siklus I sudah teratasi atau belum.

d. Refleksi

Kekurangan dan kelemahan yang terjadi pada siklus I telah dapat diatasi pada siklus II ini. 


\section{Siklus III}

a. Perencanaan

Berdasarkan hasil analisis dan refleksi pada siklus II, peneliti mengadakan diskusi dengan guru kelas untuk mengatasi kekurangan yang terjadi pada siklus II. Peneliti dan guru juga menetapkan jadwal penelitian selanjutnya.

b. Pelaksanaan

Dalam penelitian ini peneliti bertindak sebagai guru dan pengamatan dibantu oleh rekan guru. Guru membahas tentang ejaan yang disempurnakan, tata penulisan kalimat dan paragraf yang benar dengan media pembelajaran gambar seri.

c. Observasi

d. Refleksi

Proses pembelajaran pada siklus III berjalan dengan baik dan lancar.

Pelaksanaan pembelajaran pada siklus III ini siswa lebih aktif daripada siklus II. Kendalakendala yang terjadi pada siklus sebelumnya dapat diatasi dalam siklus III ini. Penelitian dihentikan sampai siklus III, karena penelitian ini dianggap telah berhasil dan hasilnya pun memuaskan.

\section{HASIL DAN PEMBAHASAN}

Dari data-data yang telah diperoleh menunjukkan bahwa penggunaan media gambar seri dapat meningkatkan kemampuan siswa dalam menulis karangan bahasa Indonesia. Penggunaan media gambar seri dapat dijadikan sebagai salah satu strategi untuk meningkatkan pembelajaran menulis karangan pada mata pelajaran bahasa Indonesia.

Berdasarkan hasil yang didapat dari siklus I, dari 39 siswa diperoleh nilai rata-rata 66,03. Siswa yang memperoleh ketuntasan dalam pembelajaran hanya 18 siswa sedangkan siswa yang belum tuntas cukup banyak yaitu 21 siswa. Artinya pembejaran yang dilaksanakan pada siklus I ini belum memperoleh hasil yang optimal. Perolehan hasil nilai kemampuan menulis siswa dalam siklus I ini dapat dinyatakan memperoleh ketuntasan sebesar $46,15 \%$. Sedangkan yang belum mencapai ketuntasan sebesar $53,85 \%$. Dalam siklus ini siswa mengalami kesulitan dalam penulisan ejaan, pemilihan kata, tata penulisan kalimat dan paragraf yang benar sehingga siswa perlu diberikan tambahan pengetahuan tentang ejaan yang disempurnakan (EYD). Siswa juga kurang tertarik dengan kegiatan menulis karangan sehingga siswa perlu diberi motilVasi dan media yang lebih menarik lagi.

Untuk hasil pengamatan terhadap guru dalam proses pembelajaran dengan menggunakan media gambar seri diperoleh skor 17 dengan rata-rata nilai 2,1. Ini bararti bahwa aktivitas guru dalam pelaksanaan pembelajaran sudah berjalan cukup baik. Namun masih ada keterampilan yang belum dikuasai dengan baik oleh guru, seperti membimbing siswa dalam membuat kerangka karangan, membimbing siswa dalam menulis karangan, berdiskusi dengan siswa, mengelValuasi hasil karangan, dan menutup pelajaran.

Hasil menulis karangan yang diperoleh dalam siklus II memperoleh rata-rata nilai sebesar 72,21. Dari nilai rata-rata tersebut siswa yang telah mencapai ketuntasan dalam pembelajaran sebanyak 28 siswa sedangkan yang belum mencapai ketuntasan sebanyak 11 siswa. Ini berarti bahwa dalam siklus II ini telah terjadi peningkatan hasil belajar. Ketuntasan yang diperoleh pada siklus II ini dapat dinyatakan dengan perolehan prosentase sebesar $71,79 \%$ sedangkan yang belum mencapai ketuntasan sebesar $26,1 \%$. Pada siklus II ini siswa sudah mulai tertarik dengan pelajaran menulis karangan. Siswa sudah mulai aktif dalam pembelajaran.

Untuk hasil pengamatan guru dalam penggunaan media gambar seri diperoleh skor 21 dengan rata-rata 2,6. Ini artinya bahwa aktivitas guru dalam pelaksanaan pembelajaran telah berjalan dengan baik, namun masih ada beberapa keterampilan yang belum dikuasai oleh guru. Walaupun demikian, hasil aktivitas yang diperoleh guru sudah berkategori baik. 
Hasil yang diperoleh siswa dalam menulis karangan pada siklus III ini diperoleh rata-rata sebesar 80,44. Siswa yang telah mencapai ketuntasan pembelajaran sejumlah 37 siswa, dengan prosentase ketuntasan $94,87 \%$ dan hanya 2 orang siswa atau sebesar $5,13 \%$ siswa yang belum tuntas.

Pada pengamatan terhadap guru dalam pembelajaran dengan penggunaan media gambar seri pada siklus III skor yang diperoleh adalah 3 dengan prosentase $94,87 \%$. Ini artinya, bahwa aktivitas guru yang menyangkut dengan keterampilan mengajar sudah berjalan dengan baik, sehingga hasil aktivitas guru pada siklus III ini telah mencapai hasil yang maksimal dengan kategori baik.

Adapun hasil data yang berkenaan dengan hasil kemampuan menulis karangan yang diperoleh siswa dalam setiap akhir proses pembelajaran yang dilakukan dalam setiap siklus dapat dilihat dalam Tabel 1.

\begin{tabular}{|c|c|c|c|c|c|}
\hline No & Pembelajaran & Nilai Rata-Rata & Siswa Tuntas & $\begin{array}{l}\text { Siswa Tidak } \\
\text { Tuntas }\end{array}$ & $\begin{array}{l}\text { Prosentase } \\
\text { Ketuntasan }\end{array}$ \\
\hline 1 & Siklus I & 66,03 & 18 & 21 & $46,15 \%$ \\
\hline 2 & Siklus II & 72,21 & 28 & 11 & $71,79 \%$ \\
\hline 3 & Siklus III & 75,2 & 23 & 0 & $100 \%$ \\
\hline
\end{tabular}

Di samping data tentang hasil kemampuan menulis karangan tersebut ada pula data hasil obervasi terhadap guru dalam pelaksanaan pembelajaran dengan penggunaan media gambar seri yang diperoleh setiap siklus dapat dilihat dalam Tabel 2.

Tabel 2. Data Perolehan Hasil Pengamatan Terhadap Guru Dalam Penggunaan Media Gambar Seri Pada Setiap Siklus

\begin{tabular}{cccc}
\hline No & Pembelajaran & Rata-Rata & Kategori \\
\hline 1 & Siklus I & 2,1 & Cukup \\
2 & Siklus II & 2,6 & Baik \\
3 & Siklus III & 3.0 & Baik \\
\hline
\end{tabular}

Dari data pada Tabel 2 menunjukkan bahwa aktivitas guru dalam penerapan media gambar seri juga mengalami peningkatan yang signifikan dalam setiap siklusnya.

Hasil penelitian ini menunjukkan bahwa penggunaan media gambar berseri merupakan tindakan yang tepat dilakukan oleh guru pada saat pembelajaran agar terjadi peningkatan kemampuan menulis karangan dalam mata pelajaran bahasa Indonesia. Hal ini dikarenakan gambar seri yang berupa kejadian beruntun/kronologis akan membantu siswa dalam menemukan gagasan dalam bercerita (Abbas, 2006). Hasil penelitian ini sejalan dengan pendapat Tari, et al. (2020) yakni metode pembelajaran merupakan salah satu hal penting dalam kegiatan belajar mengajar, maka dari itu sebelum memberikan pengajaran, seorang pendidik perlu mempertimbangkan model pembelajaran yang akan digunakan dalam proses pembelajaran yang sesuai dengan kompetensi yang dimiliki siswa. Dengan demikian perlakuan atau tindakan pada penelitian ini dapat mendukung terhadap tujuan pendidikan karena menurut Sopiah, et al. (2020) pendidikan merupakan hal penting dalam rangka meningkatkan kualitas Sumber Daya Manusia baik dari segi spiritual, intelegensi, maupun skill untuk menunjang kehidupannya.

\section{KESIMPULAN}

Berdasarkan hasil penelitian dan pembahasan maka dapat disimpulkan bahwa penggunaan media gambar seri dapat meningkatkan kemampuan siswa dalam menulis karangan dalam mata pelajaran bahasa Indonesia pada siswa kelas IV SD Negeri I Karangsambung Kota Tasikmalaya 
tahun ajaran 2017/2018. Dengan penggunaan media gambar seri proses pembelajaran dalam menulis karangan dapat meningkatkan kreatifitas siswa dalam melahirkan ide dan imajinasi untuk bercerita serta siswa lebih mudah menemukan kosa kata dan mengungkapkan isi gambar ke dalam bentuk tulisan. Pada siklus I ketuntasan belajar menulis siswa baru mencapai 46,15\% denga nilai rata-rata sebesar 66,03, dan pada siklus II ketuntasan siswa meningkat menjadi $71,79 \%$ dengan nilai rata-rata 72,21 , selanjutnya pada siklus III ketuntasan belajar siswa menjadi lebih meningkat menjadi $94,87 \%$ dengan nilai rata-rata sebesar 80,44 , maka pembelajaran di akhiri dan tidak dilanjutkan ke siklus berikutnya karena sudan mencapai indikator yang sudah di tetapka yaitu nilai KKM sebesar 75. Berdasarkan penelitian yang dilakukan, maka disajikan saran adalah guru sebaiknya membimbing siswa secara intensif dan merata dalam pembelajaran menulis karangan.

\section{REKOMENDASI}

Rekomendasi dari penelitian ini adalah guru sebaiknya dapat memilih metode dan media yang sesuai agar menarik minat dan perhatian siswa dalam menulis bias juga melibatkan teknologi di dalamnya.

\section{UCAPAN TERIMAKASIH}

Penulis mengucapan terima kasih kepada guru kelas IV dan kepala SD Negeri I Karangsambung Kota Tasikmalaya yang telah medukung terhadap pelaksanaan penelitian ini.

\section{DAFTAR PUSTAKA}

Abbas, S. (2006). Pembelajaran Bahasa Indonesia yang Efektif di Sekolah Dasar. Jakarta: Dirjen Dikti Depdiknas.

Afifah, A. N., Ilmiyati, N \& Toto. (2020). Pengaruh Model Project Based Learning (PjBL) dengan Pendekatan STEM Terhadap Penguasaan Konsep dan Keterampilan Berpikir Kritis Siswa. J-KIP (Jurnal Keguruan dan IImu Pendidikan), 1(2), 33-40.

Putra, N. A. (2016). Penggunaan Media Gambar Seri untuk Meningkatkan Keterampilan Menulis Narasi pada Mata Pelajaran Bahasa Indonesia Siswa Kelas IV SDN Moahino Kabupaten Morowali. Jurnal Kreatif Tadulako, 2(4), 230-242.

Slamet, S. Y. (2007). Dasar-dasar Pembelajaran Bahasa dan Sastra Indonesia di Sekolah Dasar. Surakarta: UNS Press.

Sopiah, E, S., Effendi, A., \& Sunaryo, Y. (2020). Analisis Kemampuan Berpikir Kreatif Matematis Siswa Kelas VIII pada Materi Sistem Persamaan Linear Dua Variabel (SPLDV). J-KIP (Jurnal Keguruan dan IImu Pendidikan), 1(2), 1-10.

Tari, H. D ., Suwirta, U \& Dedeh. (2020). Pengaruh Penerapan Model Pembelajaran Kooperatif Tipe Teams Games Tournament (TGT) terhadap Hasil Belajar Siswa pada Mata Pelajaran Ekonomi di MAN 2 Kota Tasikmalaya. J-KIP (Jurnal Keguruan dan Ilmu Pendidikan), 1(2), 19-26.

Tarigan, H. G. (1987). Teknik Pengajaran Ketrampilan Berbahasa. Bandung: Angkasa. 